\title{
NECESSIDADES DE CUIDADO DA PARTURIENTE
}

\author{
THE NECESSITIES OF CARE OF THE PARTURIENT
}

EL CUIDADO QUE HAY QUE DAR A UNA PARTURIENTE

\author{
Autora: Suzete Maria Fustinoni \\ Orientadora: Miriam Aparecida Barbosa Merighi
}

\begin{abstract}
Este estudo teve como trajetória desvelar o fenômeno da assistência às mulheres em trabalho de parto e parto, sob a ótica de quem realiza a ação de assistir e de quem recebe a assistência. Assim, com o objetivo de compreender o significado da assistência com base no vivido das pessoas envolvidas nesta relação, busquei a compreensão do típico da vivência de gestantes e enfermeiras obstetras em ações que envolvam este momento especifico do processo de parturição. Ao desenvolver a proposta de investigação do estudo, fundamentei-o no referencial teórico metodológico da Sociologia Fenomenológica de Alfred Schütz, considerando que as pessoas expressam em suas ações socialmente vividas os significados dessas vivências. Com esta perspectiva, busquei os depoimentos por meio da entrevista fenomenológica com a seguinte questão orientadora à gestante: O que a Senhora espera do profissional que irá atendê-la em seu trabalho de parto e parto? Às enfermeiras, utilizei as seguintes perguntas: Como você faz o atendimento de um mulher em trabalho de parto e parto? O que você espera com esse atendimento? A análise dos depoimentos foi realizada com a finalidade de identificar categorias concretas que expressam aspectos significativos da vivência, considerando os motivos para que determinam a relação de seus atos. Pela análise concreta do vivido, cheguei à tipologia dos dois grupos sociais. Desta forma, o tipo vivido gestante mostrou-se sendo aquele profissional que promove informação e explicação de seu estado de saúde e do filho, em linguagem acessivel e também demonstra competência técnica, necessária ao atendimento, mantendo uma relação de proximidade e respeitando suas peculiaridades pelo contato humano. O tipo vivido enfermeira obstetra é o que objetiva promover uma interação com a parturiente, em que seja possivel transmitir segurança e tranqüilidade, orientação e informação sobre a evolução de seu trabalho de parto e parto. Propiciando, assim, sua participação na assistência prestada no período. A Sociologia Fenomenológica possibilitou a compreensão dos motivos alegados pelos dois grupos sociais que apontam para uma assistência ao trabalho de parto e parto tendo em vista uma ação com respeito mútuo, dignidade, empatia, envolvimento e acolhimento.
\end{abstract}

